\title{
A CLÁUSULA DE RESERVA DE PLENÁRIO SEGUNDO OS TRIBUNAIS DE JUSTIÇA
}

\author{
FÁBIO CARVALHO LEITE ${ }^{1}$
}

\begin{abstract}
RESUMO: De acordo com a cláusula de reserva de plenário, os Tribunais só podem declarar a inconstitucionalidade de uma lei pelo voto da maioria absoluta de todos os seus membros. A Lei n. 9756/1998 alterou o artigo 481 do Código de Processo Civil (CPC), que regulamenta a cláusula de reserva de plenário, estabelecendo que órgãos fracionários dos tribunais não submeterão ao plenário, ou ao órgão especial, a argüição de inconstitucionalidade, quando já houver pronunciamento destes ou do plenário do Supremo Tribunal Federal sobre a questão. Esta norma sugere que, quando os órgãos fracionários entenderem que a lei é inconstitucional, estarão dispensados de encaminhar a questão ao plenário (ou ao órgão especial) se já houver decisão deste ou do STF sobre a questão. Contudo, outra interpretação desta norma indica que os órgãos fracionários estarão sempre vinculados à jurisprudência do STF sobre a constitucionalidade das leis, não podendo decidir de forma diferente. O propósito deste trabalho é investigar, a partir da análise dos Regimentos Internos dos Tribunais de Justiça, como estes órgãos do Poder Judiciário interpretam a cláusula de reserva de plenário (art. 481, CPC).

PALAVRAS-CHAVE: Controle de Constitucionalidade; Cláusula de Reserva de Plenário; Supremo Tribunal Federal.
\end{abstract}

ABSTRACT: According to the "full bench" clause, the courts can only declare the unconstitutionality of an act by the absolute majority of its members vote. The act 9756/1998 changed the article 481 of the Civil Procedure Code (CPC), which disciplines the full bench clause, and established that the division court shall not submit the question of unconstitutionality to the full bench of the Court, or its special court, if there's already a Supreme Court decision about that question. This act suggests that, when the division courts decides that the act is unconstitutional, they won't need to submit the question to the full bench of the Court (or its special court) if there's already a Supreme Court decision about that question. However, another interpretation of that act (art. 481, CPC) indicates that the division courts will always be obligated to decide according to the Supreme Court decisions about the constitutionality of acts, and they can never decide differently. The present paper aims to identify, trough the analyses of the

Artigo recebido em 24.02.2011. Pareceres emitidos em 07.04.2011 e 11.04.2011.

Artigo aceito para publicação em 31.05.2011.

${ }^{1}$ Professor de Direito Constitucional dos Cursos de Graduação, Mestrado e Doutorado da PUC-Rio. Coordenador (adjunto) do Curso de Pós-Graduação (stricto sensu) da PUC-Rio. Mestre em Teoria do Estado e Direito Constitucional (PUC-Rio) e Doutor em Direito Público (UERJ). Coordenador do Núcleo de Estudos Constitucionais da PUC-Rio. Assessor Jurídico da Reitoria da PUC-Rio. Secretário Geral da Comissão de Ensino Jurídico da OAB-RJ. fabiojur@puc-rio.br 
Courts of Justice's internal acts, how this Courts interpret the full bench clause (art. 481, CPC).

KEYWORDS: Judicial Review. The Full Bench Clause. Brazilian Supreme Court.

SUMÁRIO: Introdução; 1. Considerações sobre a cláusula de Reserva de Plenário; 2. A cláusula de Reserva de Plenário na visão dos Tribunais; 3. Análises e Conclusões.

SUMMARY: Introduction; 1 . Considerations about the "full bench" clause; 2 . The "full bench" clause according to the Courts of Justice; 3 . Analyses and conclusions.

\section{INTRODUÇÃO}

O Brasil possui hoje um complexo sistema de controle de constitucionalidade das leis, que em muito se distancia da caracterização simplista de um modelo híbrido, composto pelos controles difuso e concentrado - modelo que, se não era simples em sua natureza, era ao menos assim apresentado. Grosso modo, a compreensão do controle de constitucionalidade no Brasil, em sede doutrinária, resumia-se basicamente à análise quase estática de dois modelos distintos, com origens e características igualmente distintas, e cuja convivência gerava o modelo misto brasileiro.

Mudanças neste modelo (ou nesta compreensão de modelo) foram realizadas não pela Constituição de 1988 (doravante CRFB), mas seguramente a partir dela ${ }^{2}$. E, nesse sentido, embora as mudanças mais visíveis tenham ocorrido no plano do controle abstrato-concentrado, assume-se aqui que mudanças sensíveis ocorreram no plano do controle concreto-difuso, inclusive, mas não necessariamente como decorrência das primeiras.

Se, num plano meramente formal, é possível afirmar que o modelo concreto-difuso adotado pela Constituição de 1988 é o mesmo que foi definido pela Constituição de 1934, e mantido pelos regimes posteriores (à exceção da Carta de 1937), na prática esta afirmação simplesmente não procede. Basta lembrar que, a partir do advento da Ação Declaratória de Constitucionalidade (doravante $A D C$ ), tornou-se legítimo impedir que um juiz ou tribunal declare a inconstitucionalidade de uma lei (federal), no exame de um caso concreto, se o ato normativo em questão tiver sido objeto de ADC julgada procedente - idéia no mínimo estranha ao modelo definido em 1934.

São outras, no entanto, e mais sensíveis (ou menos visíveis) as mudanças que pretendo investigar neste trabalho. $O$ objeto do presente artigo restringe-se à análise da forma como a cláusula de reserva de plenário (art. 97, CRFB), imposta aos Tribunais desde 1934, tem sido compreendida no atual sistema de controle de constitucionalidade brasileiro (ou como foi por ele afetada). Dentre as alterações sofridas a partir da Constituição de 1988, destaca-se aqui a redação dada pela Lei 9.756/98 ao parágrafo único do art. 481 do Código de Processo Civil (doravante CPC), segundo a qual "os órgãos fracionários

${ }^{2}$ LEITE, Fábio Carvalho. ADIN e ADC, e a ambivalência possível: uma proposta. In: Revista de Direito do Estado (RDE), vol. 10, Rio de Janeiro: Ed. Renovar, 2008, pp. 67-68. 
dos tribunais não submeterão ao plenário, ou ao órgão especial, a argüição de inconstitucionalidade, quando já houver pronunciamento destes ou do plenário do Supremo Tribunal Federal sobre a questão". Trata-se de um enunciado aparentemente simples (e assim tem sido apresentado pela doutrina processualista e até constitucionalista, quando esta se aprofunda minimamente sobre o tema), mas que oculta algumas questões que podem se revelar polêmicas, dentre as quais destaco: (i) a decisão do STF pela inconstitucionalidade (em controle difuso, é claro ${ }^{3}$ ) vincula o órgão fracionário? (ii) e se for uma decisão (também pela inconstitucionalidade) tomada pelo órgão especial ou pelo plenário do Tribunal? (iii) e se a decisão (tanto do STF, como do plenário dos Tribunais ou de seu órgão especial) for pela constitucionalidade do ato normativo? Estarão os órgãos fracionários vinculados ao que houver sido decidido? (iv) e se houver decisão do STF pela constitucionalidade e decisão do pleno do Tribunal ou de seu órgão especial pela inconstitucionalidade da lei? (v) e se for o contrário (decisão do STF pela inconstitucionalidade e do pleno pela constitucionalidade da lei)?

O propósito deste trabalho é, em primeiro lugar, testar a validade destas perguntas, mais do que simplesmente tentar respondê-las. Até porque 0 valor destas respostas está condicionado à validade do problema sugerido. Nesse sentido, pretendo identificar e analisar o modo como os regimentos internos dos tribunais regularam a cláusula de reserva de plenário. Assumo de início que os regimentos dos tribunais não são uniformes no tratamento da matéria e sugiro que divergências normativas nesse sentido podem apontar para diferentes compreensões acerca das mudanças trazidas pela legislação processual àquele mandamento constitucional.

Para alcançar os limitados objetivos deste trabalho, uma análise dos regimentos de todos os tribunais do País - universo que abrange os órgãos da justiça comum (estadual e federal) e especializada (militar, eleitoral e trabalhista) - seria excessiva e desnecessária. De todo modo, ainda que um universo mais restrito de análise seja suficiente, revela-se útil reunir um conjunto relativamente vasto de regimentos que permita identificar o grau de divergência na leitura da cláusula de reserva de plenário, segundo a norma processual, razão pela qual escolhi como objeto de análise os regimentos dos 27 tribunais de justiça.

Antes de abordar os regimentos, contudo, é importante fazer algumas considerações acerca da cláusula de reserva de plenário.

1. CONSIDERAÇõES SOBRE A CLÁUSULA DE RESERVA DE PLENÁRIO

A cláusula constitucional de reserva de plenário (art. 97) encontra-se disciplinada em legislação ordinária nos arts. 480 e 481 do CPC. De acordo com estes dispositivos legais, quando uma questão de inconstitucionalidade

\footnotetext{
${ }^{3}$ A decisão do STF a que se refere o dispositivo legal só pode ser aquela tomada em sede de controle concreto-difuso, já que as decisões proferidas em sede de controle abstrato-concentrado já possuem eficácia erga omnes e efeito vinculante.
} 
for suscitada perante um órgão fracionário de um Tribunal (Câmara ou Turma do Tribunal), no julgamento de um caso concreto, o relator, depois de ouvir o representante do Ministério Público (MP), deverá, independentemente do entendimento deste, submeter a questão aos demais magistrados que integram o referido órgão fracionário. Caso os magistrados, por maioria, entendam que a norma impugnada é constitucional, deverão prosseguir com o julgamento. Caso entendam, por maioria, que se trata de norma inconstitucional, deverão suspender o julgamento, lavrar acórdão nesse sentido, e encaminhar a questão ao pleno do Tribunal - ou ao órgão especial, se houver.

Esta cisão funcional que ocorre no âmbito dos Tribunais torna clara a distinção entre a questão prejudicial de constitucionalidade da lei e o mérito do caso sub judice, questões que de certo modo se misturam quando o controle de constitucionalidade ocorre nos juízos monocráticos (e justamente porque são monocráticos) de primeira instância. De fato, um juiz de primeira instância, no julgamento de um processo onde é suscitada a inconstitucionalidade de uma lei, e confirmando ser esta uma questão prejudicial, deverá, no fundamento da sentença, se pronunciar pela constitucionalidade ou inconstitucionalidade da lei em questão, para então, no dispositivo da sentença, decidir o caso concreto (se julga procedente ou improcedente o pedido; se concede ou denega a ordem pleiteada).

A título de ilustração, considere-se o seguinte exemplo: um cidadão se inscreveu no vestibular para um concorrido curso de ensino superior oferecido por uma universidade pública estadual, para o qual uma lei do respectivo estado havia estabelecido uma reserva de vagas para negros. Não tendo sido aprovado no exame, o cidadão decide impetrar mandado de segurança, sob o fundamento de que a referida lei é inconstitucional. No julgamento do mandado de segurança, o juiz deverá antes verificar se a suposta inconstitucionalidade da lei é questão prejudicial ao pedido formulado pelo impetrante - é dizer, se a concessão ou não da ordem depende de um juízo acerca da constitucionalidade da lei. Assim, se o cidadão foi reprovado porque tirou zero em uma das disciplinas do vestibular, e o edital estabelecia que um candidato nesta situação seria considerado automaticamente reprovado, então o juízo sobre a constitucionalidade da lei torna-se desnecessário ao julgamento do processo, e a ordem de segurança será denegada. Se não for este o caso, mas, depois de impetrada a ação, o cidadão tiver sido aprovado, por conta da desistência de outros candidatos com pontuação superior à dele (reclassificação), o juízo sobre a constitucionalidade da lei torna-se também neste caso desnecessário ao julgamento do processo, e o mandado de segurança será extinto sem julgamento de mérito, por falta de interesse processual. Por outro lado, se o juiz verificar que o pretendido direito à vaga no curso universitário depende do exame da constitucionalidade da lei - é dizer, se ela fosse inconstitucional, o cidadão seria considerado aprovado -, então, neste caso, pode-se afirmar que a decisão sobre a constitucionalidade do ato normativo é uma questão prejudicial ao processo. 
Neste exemplo citado, o juiz de primeira instância (órgão monocrático) deverá se manifestar sobre a constitucionalidade da lei no fundamento da sentença, para, no dispositivo, se pronunciar sobre o pedido - se concede ou não a ordem pleiteada. Não há, portanto, cisão funcional: o mesmo juiz se pronuncia sobre a constitucionalidade da lei e sobre o pedido da ação judicial.

Já no tribunal (órgão colegiado), a questão constitucional recebe tratamento diverso. Embora o órgão julgador do caso concreto (Turma ou Câmara) possa, assim como o juiz de primeira instância, considerar a lei constitucional e, a partir deste entendimento, julgar o pedido do processo, o mesmo não se pode afirmar quando o referido órgão considera a lei inconstitucional. Neste caso, como visto, o órgão fracionário (Turma ou Câmara) deverá encaminhar a questão constitucional ao pleno do Tribunal (ou ao órgão especial, se houver) ${ }^{4}$ para que confirme ou rejeite o entendimento pela inconstitucionalidade da lei. Para a confirmação da inconstitucionalidade da lei, é necessário que a maioria dos magistrados do pleno do Tribunal entenda que a lei é inconstitucional. Não atingido este quorum, a lei será considerada constitucional, ainda que a maioria relativa tenha entendido de outra forma.

Tanto a exigência de pronunciamento do pleno como a do quorum de maioria absoluta fundamentam-se a partir do mesmo princípio: o da presunção de constitucionalidade das leis. É por este motivo que nem o órgão fracionário (Câmara ou Turma) nem a maioria relativa do pleno podem considerar a lei inconstitucional. Dito de outra forma, esta é a razão que sustenta a regra conhecida como reserva de plenário (introduzida pela Constituição de 1934).

Assim, caso o pleno considere a lei constitucional (ou porque a maioria dos seus membros entendeu desta forma ou porque só a maioria relativa entendeu pela inconstitucionalidade da lei), o órgão fracionário deverá julgar o caso concreto assumindo que a lei é constitucional, ainda que este não tenha sido o seu entendimento inicial $\left.\right|^{5}$. No entanto, a decisão do pleno não determina o julgamento do órgão fracionário sobre o caso concreto; apenas exclui a hipótese de inconstitucionalidade da lei como razão para decidir, podendo o órgão fracionário, a partir de outros fundamentos (como prescrição ou decadência, por exemplo, que podem ser argüidos a qualquer momento no processo), alcançar o mesmo resultado a que chegaria se pudesse considerar a lei inconstitucional.

Esta forma de apresentação do significado e modo de aplicação da cláusula de reserva de plenário, contudo, é satisfatória apenas para a compreensão mais básica da regra. É dizer, este exemplo descreve o modo

\footnotetext{
${ }^{4}$ Doravante, citarei apenas o Tribunal Pleno, devendo-se compreender que o mesmo valerá para o órgão especial, onde houver.

${ }^{5}$ Esta divergência, contudo, não deve causar espanto. Afinal, o que enseja a manifestação do pleno ou órgão especial (que pode entender pela constitucionalidade da lei) será sempre e necessariamente um entendimento prévio do órgão fracionário pela inconstitucionalidade da norma.
} 
como funciona a referida cláusula quando a arguição de inconstitucionalidade é suscitada pela primeira vez por um órgão fracionário e decidida, também pela primeira vez, pelo tribunal pleno. Mas é justamente a partir deste primeiro pronunciamento do Tribunal que a questão torna-se mais complexa. Afinal, quais são os efeitos desta decisão tomada pelo tribunal pleno para os casos futuros, em que se discuta a constitucionalidade da mesma lei? Se o pleno tiver decidido pela inconstitucionalidade, poderá um órgão fracionário, num caso futuro, aplicar a lei, por considerá-la constitucional? Ou estará vinculado à declaração de inconstitucionalidade do tribunal pleno?

O entendimento de que a decisão tomada pelo tribunal pleno vincula os órgãos fracionários para a análise de casos futuros, embora pareça uma decorrência lógica, esbarra em algumas dificuldades.

O parágrafo único do art. 481 do Código de Processo Civil dispõe que, quando já houver pronunciamento do plenário ou do órgão especial, "os órgãos fracionários dos tribunais não submeterão" a estes a argüição de inconstitucionalidade. Ocorre que os órgãos fracionários somente submetem ao pleno a arguição quando entendem que a lei é inconstitucional, mas não quando consideram a lei constitucional, pois o valor que sustenta a regra da reserva de plenário é a de presunção de constitucionalidade das leis.

Poder-se-ia assim argumentar que o dispositivo citado vale apenas para aquelas situações em que os órgãos fracionários entendem que a lei é inconstitucional. Nesses casos, o órgão fracionário estaria dispensado de submeter a arguição ao pleno ("não submeterão") justamente por já haver um pronunciamento deste.

A idéia de vinculação dos órgãos fracionários ao pronunciamento do pleno enfrenta ainda outra dificuldade. É que o parágrafo único do art. 481 afirma que "os órgãos fracionários dos tribunais não submeterão ao plenário, ou ao órgão especial, a argüição de inconstitucionalidade" não apenas quando já houver pronunciamento destes, mas também quando houver pronunciamento "do plenário do Supremo Tribunal Federal". Se entendermos que se trata de vinculação, e assumindo, por hipótese, que haja pronunciamentos do STF e do pleno do Tribunal em sentidos opostos (um pela constitucionalidade e outro pela inconstitucionalidade), a qual destes estaria o órgão fracionário vinculado? Afirmar que o órgão fracionário estaria vinculado à decisão do STF - por ser instância superior, órgão de cúpula do Poder Judiciário ou guardião da Constituição (argumento de que têm se valido alguns ministros para avocar ao STF praticamente um monopólio na interpretação do texto constitucional) - subverteria de certo modo o sistema de controle de constitucionalidade brasileiro, pois uma decisão tomada pelo STF em controle concreto-difuso vincularia os tribunais (segunda instância), embora não afetasse os juízes de primeira instância. Por outro lado, afirmar que o entendimento que vincularia seria o do pleno do Tribunal deixaria dúvidas a respeito do critério para se chegar a esta posição, pois a norma processual não faz distinção entre os pronunciamentos do STF e do pleno do Tribunal. 
Mais uma vez, a idéia de que o dispositivo citado vale apenas para os casos em que os órgãos fracionários entendem que a lei é inconstitucional parece melhor. Desse modo, entenderíamos que o órgão fracionário estaria dispensado de submeter a arguição ao pleno (reserva de plenário) por já haver um pronunciamento (seja do STF seja do próprio pleno do Tribunal) que o autorizaria a julgar o caso concreto a partir da premissa de que a lei é inconstitucional, ou, por outra, o autorizaria a afastar a premissa de presunção de constitucionalidade da lei (valor que justifica a observância da regra de reserva do plenário).

Este entendimento, contudo, não está isento de dúvidas. É que o dispositivo do CPC, ao tratar da decisão do STF e/ou do tribunal pleno ou órgão especial que dispensaria o procedimento da reserva de plenário, não faz referência expressa e específica a decisões pela inconstitucionalidade. Segundo o dispositivo processual, os órgãos fracionários dos tribunais não submeterão ao plenário, ou ao órgão especial, a argüição de inconstitucionalidade "quando já houver pronunciamento destes ou do plenário do Supremo Tribunal Federal sobre a questão". E "pronunciamento sobre a questão" é certamente uma expressão de alcance mais amplo do que "decisão pela inconstitucionalidade da lei".

Esta compreensão mais ampla, abarcando qualquer entendimento do STF sobre a questão, seja pela constitucionalidade, seja pela inconstitucionalidade, certamente satisfaria os desejos das correntes que associam o dever de guarda da Constituição, conferido ao STF, a praticamente um monopólio na interpretação da Lei Fundamental. Mas, para além das críticas que podem ser dirigidas a esta premissa, deve-se também recordar que as declarações de constitucionalidade em sede de controle concretodifuso, mesmo quando proferidas pelo STF, não possuem efeito vinculante. Aliás, a declaração de constitucionalidade com efeito vinculante foi uma idéia incorporada ao direito brasileiro a partir do advento da Ação Declaratória de Constitucionalidade, que, vale lembrar, só pode ter por objeto lei ou ato normativo federal, e somente pode ser ajuizada após comprovada a existência de controvérsia judicial relevante. A súmula vinculante, trazida pela EC 45/2004, alargou a possibilidade de declaração de constitucionalidade com tal efeito, eis que não há restrição quanto à espécie de ato normativo (federal, estadual ou municipal; primário ou secundário, etc). Por outro lado, para a edição de uma súmula vinculante, é necessário que haja reiteradas decisões num mesmo sentido, o que impede, como decorrência lógica, que uma única decisão num caso concreto tenha o mesmo efeito que uma súmula vinculante, editada após reiteradas manifestações do STF.

Assim, parece que a melhor interpretação do dispositivo processual seria a de que o órgão fracionário, como decorrência do princípio da presunção de constitucionalidade dos atos normativos, estará sempre autorizado a aplicar uma lei, mesmo que haja decisão do STF ou do tribunal pleno, em sede de 
controle concreto-difuso, pela inconstitucionalidade da norma, e só não poderá fazê-lo caso a declaração de inconstitucionalidade decorra do controle abstrato-concentrado ou de súmula vinculante, hipóteses em que o órgão fracionário não poderá aplicar a lei.

Por outro lado, caso o órgão fracionário entenda que a lei é inconstitucional, deve-se assumir que, a princípio, estará obrigado a encaminhar a questão ao pleno - dever que somente será afastado se já houver decisão ou do STF ou do próprio pleno no mesmo sentido. Não se trata, como visto, de vinculação ao que fora decidido pelo STF ou pelo pleno. Simplesmente, neste caso, a existência de uma declaração de inconstitucionalidade afastaria a presunção de constitucionalidade da lei e, pelo disposto no CPC, autorizaria o órgão fracionário a não submeter a questão ao pleno.

Nesse sentido, caso o órgão fracionário entendesse pela inconstitucionalidade total de uma lei e houvesse decisão do STF pela inconstitucionalidade parcial da mesma, o órgão fracionário poderia ou deixar de aplicar a lei em parte (seguindo a decisão do STF) ou encaminhar a questão ao pleno (caso insistisse pela inconstitucionalidade total). Se, ainda nesta hipótese, o pleno entendesse pela constitucionalidade da norma, de todo modo o órgão fracionário poderia deixar de aplicar a parte considerada inconstitucional pelo STF.

Estes pontos aqui levantados, e que animam o presente trabalho, não são "problematizados" pela doutrina, quando esta discorre sobre a cláusula de reserva de plenário, em geral, e sobre o art. 481, parágrafo único do CPC, em particular. O resultado, contudo, não deixa de ser curioso. Não havendo problemas a serem resolvidos ou questões a serem respondidas, os autores expõem suas interpretações sem maiores justificativas ${ }^{6}-$ talvez em razão de uma suposta clareza da norma. Ocorre que as leituras defendidas pelos autores são divergentes, o que confirma a polêmica que eles negam existir.

Fredie Didier Jr. e Leonardo Carneiro da Cunha, por exemplo, ao discorrerem sobre o art. 481, parágrafo único do CPC, são categóricos ao afirmarem que a decisão proferida pelo pleno (ou órgão especial) "tem eficácia vinculativa para o tribunal" ${ }^{\prime 7}$. Os autores citam, no mesmo sentido, José Levi Mello do Amaral Jr., que afirma que "a decisão do tribunal pleno não valerá somente para o caso concreto em que surgiu a questão de constitucionalidade.

\footnotetext{
${ }^{6}$ Considero aqui os processualistas, pois a doutrina de direito constitucional, quando muito, apenas cita o dispositivo em sua leitura mais óbvia, sem esclarecer como o interpreta diante das questões aqui levantadas (AGRA, Walber de Moura. Curso de Direito Constitucional. 4. ed. Rio de Janeiro: Forense, 2008, p. 602; BARROSO, Luís Roberto. O Controle de Constitucionalidade no Direito Brasileiro. 3. ed. São Paulo: Saraiva, 2008, p. 87)

7 DIDIER JR., Fredie, e CUNHA, Leonardo Carneiro da. Curso de Direito Processual Civil meios de impugnação às decisões judiciais e processo nos tribunais. 9. ed. Vol. 3. Salvador: Editora Podium, 2011, p. 577.
} 
Será paradigma (leading case) para todos os demais feitos - em trâmite no tribunal - que envolvam a mesma questão" ${ }^{\text {. }}$.

Nelson Nery Jr. e Rosa Maria de Andrade Nery, por outro lado, interpretam o parágrafo único do art. 481 do CPC como "medida de economia processual", observando que na situação descrita pelo dispositivo processual "o órgão fracionário pode aplicar a decisão anterior do plenário do STF ou do próprio tribunal, que haja considerado constitucional ou inconstitucional a lei questionada", com a ressalva de que "não há vedação de que o órgão fracionário submeta a questão ao plenário ou órgão especial, notadamente quando houver fundamento novo ou modificação na composição do plenário ou órgão especial, circunstância que caracteriza a potencialidade de modificação daquela decisão anterior" ${ }^{\prime 10}$.

Humberto Theodoro Jr. não confere especial atenção ao parágrafo único do art. 481 do CPC, mas afirma que a vinculação do órgão fracionário à decisão do pleno (ou do órgão especial) é apenas para o caso concreto dos autos, podendo, perfeitamente, voltar a ser discutido o acerto, ou não, do entendimento em hipóteses futuras"11. E cita José Carlos Barbosa Moreira, para quem "a eficácia do pronunciamento é só intraprocessual"12.

Já o processualista Alexandre Câmara é categórico ao afirmar que a eficácia do pronunciamento do órgão julgador do incidente de inconstitucionalidade "é exclusivamente endoprocessual, nada havendo que determine sua força obrigatória ad futurum"13. O autor chega a considerar o disposto no parágrafo único do art. 481 do CPC, "para dizer o mínimo, de constitucionalidade duvidosa". E prossegue:

\footnotetext{
${ }^{8}$ AMARAL JR., José Levi Mello do. Incidente de Arguição de Inconstitucionalidade. São Paulo: RT, 2002, p. 39, apud. DIDIER JR., Fredie, e CUNHA, Leonardo Carneiro da. Curso de Direito Processual Civil - Meios de Impugnação às Decisões Judiciais e Processo nos Tribunais. 9. ed. Vol. 3. Salvador: Editora Podium, 2011, p. 577.

${ }^{9}$ Elpídio Donizetti segue linha semelhante. Afirma que "essa nova feição dada [pelo art. 481, parágrafo único do $\mathrm{CPC}$ ] ao incidente de inconstitucionalidade significa que o legislador optou por dar eficácia vinculante aos pronunciamentos dos órgãos superiores" e que, "em face da vedação da remessa do incidente de inconstitucionalidade aos órgãos originariamente competentes para apreciá-lo, a eficácia acerca de questão prejudicial (a constitucionalidade ou inconstitucionalidade argüida) anteriormente decidida passou a operar ultra partes". No entanto, ressalta que "nada obsta que o órgão fracionário submeta a questão ao plenário ou órgão especial, mormente quando houver fundamento novo". (DONIZETTI, Elpídio. Curso Didático de Direito Processual Civil. 6. ed. Belo Horizonte: Del Rey, 2005, p. 347.)

${ }^{10}$ NERY JR., Nelson, e NERY, Rosa Maria de Andrade. Código de Processo Civil Comentado e Legislação Processual Civil Extravagante em Vigor. 6. ed. São Paulo: Editora Revista dos Tribunais, 2002, p. 790.

${ }^{11}$ THEODORO JR., Humberto. Curso de Direito Processual Civil. 40. ed. Vol. 1. Rio de Janeiro: Editora Forense, 2002, p. 599.

${ }^{12}$ Apud. THEODORO JR., Humberto. Curso de Direito Processual Civil. 40. ed. Vol. 1. Rio de Janeiro: Editora Forense, 2002, p. 599.

${ }^{13}$ CAMARA, Alexandre Freitas. Lições de Direito Processual Civil. 2 ed., vol. II. Rio de Janeiro: Lúmen Júris, 1999, p. 36.
} 
Trata-se de mais uma tentativa de estabelecer eficácia vinculante a decisões judiciais, o que - ao menos no caso em exame - viola a garantia constitucional do contraditório. A decisão sobre a prejudicial de constitucionalidade proferida num processo não pode produzir efeitos em outros, em que são diferentes as partes, pois com isso se estará fazendo com que uma decisão judicial produza efeitos sobre pessoas que não tiveram oportunidade de influir na formação da decisão anteriormente proferida. $^{14}$

Nota-se, portanto, que os autores oferecem leituras distintas acerca do dispositivo legal sem (ao que parece) a compreensão de que estão tomando posição diante de questões polêmicas. Nesse sentido, a análise da regulamentação da cláusula de reserva de plenário nos regimentos internos dos 27 Tribunais de Justiça do País tem o propósito não apenas de identificar como estes órgãos interpretaram esta regra, mas também de oferecer subsídios para a doutrina reavaliar sua posição à luz da divergência sobre o tema.

\section{A CLÁUSULA DE RESERVA DE PLENÁRIO NA VISÃO DOS TRIBUNAIS}

As normas regimentais relativas à cláusula de reserva de plenário não apresentam divergências ou peculiaridades no que tange aos elementos mais básicos do princípio: suspensão do julgamento no órgão fracionário, encaminhamento da questão constitucional ao pleno, quorum de maioria absoluta para a declaração de inconstitucionalidade, vinculação do órgão fracionário ao que for decidido pelo pleno. O ponto que interessa ser aqui investigado, onde aí sim as divergências e peculiaridades podem se fazer presentes, é se e, em caso afirmativo, como os Tribunais de Justiça disciplinam os efeitos futuros de uma decisão tomada pelo pleno, ou mesmo pelo STF, nos termos do que dispõe o parágrafo único do art. 481 do CPC.

A primeira questão ("se") decorre mais de curiosidade do que de interesse. Afinal, a norma do código processual haverá de ser aplicada independentemente de previsão regimental, que seria neste caso mera reprodução. A segunda questão ("como") é a que efetivamente mais importa. Divergências e peculiaridades a este respeito identificadas nos regimentos dos tribunais sugerem diferenças na interpretação da regra e na compreensão do valor que a sustenta.

Nesse sentido, observo desde já que os regimentos dos tribunais do Ceará $^{15}$, Piaui ${ }^{16}$ e Alagoas ${ }^{17}$ nada dispuseram sobre efeitos futuros da decisão

\footnotetext{
${ }^{14}$ CAMARA, Alexandre Freitas. Lições de Direito Processual Civil. 2 ed., vol. II. Rio de Janeiro: Lúmen Júris, 1999, p. 37.

15 Art. 110. Somente pelo voto da maioria absoluta de seus membros, poderá o Tribunal declarar a inconstitucionalidade de lei ou de ato normativo do Poder Público.

${ }^{16}$ Art. 322. Somente pelo voto da maioria absoluta de seus membros, poderá o Tribunal de Justiça declarar a inconstitucionalidade de lei ou ato do poder público.

17 Art. 335. Somente pelo voto da maioria absoluta de seus membros, poderá o Tribunal de Justiça declarar a inconstitucionalidade de lei ou ato normativo do poder público.
} 
tomada pelo pleno, limitando-se a disciplinar apenas o procedimento a ser observado no caso do surgimento de um incidente de inconstitucionalidade perante um órgão fracionário.

Os regimentos dos tribunais de justiça do Acre $^{18}$ e do Distrito Federal ${ }^{19}$ também pouco dispõem sobre a matéria. Apenas acrescentam, se comparados com os regimentos dos tribunais citados anteriormente, que, uma vez declarada a inconstitucionalidade pelo Tribunal Pleno, os órgãos fracionários poderão reconhecê-la em outros casos, sem a necessidade de submeter novamente a questão ao Pleno - o que é parte do que dispõe o parágrafo único do art. 481 do CPC. Todavia, é curioso registrar que ambos os regimentos consideraram apenas decisões pela inconstitucionalidade do Tribunal Pleno (Acre) ou do Conselho Especial (Distrito Federal), e não "pronunciamentos sobre a questão" (redação da norma processual).

Já os regimentos dos tribunais de Goiás ${ }^{20}$ e Sergipe ${ }^{21}$ reproduzem integral e fielmente o disposto no parágrafo único do art. 481 do CPC, incluindo o "pronunciamento" do STF como decisão autorizadora do não encaminhamento do incidente de inconstitucionalidade para a apreciação do pleno.

Estes 7 tribunais citados, como se pode notar, não impõem aos órgãos fracionários um dever de seguir, em casos futuros, a decisão tomada pelo pleno. Em outras palavras, não estabelecem uma vinculação entre a decisão do pleno e os casos futuros a serem julgados pelos órgãos fracionários. Já os outros 20 tribunais admitem, a partir de critérios distintos, esta possibilidade.

De fato, os regimentos dos tribunais do Rio de Janeiro, Espírito Santo, Roraima, Rio Grande do Sul, Maranhão e Pernambuco prevêem hipóteses em que a decisão do pleno, tanto pela inconstitucionalidade como pela constitucionalidade de uma lei, será de aplicação obrigatória para todos os órgãos do tribunal.

No caso do Rio de Janeiro, se for proferida por 17 (dezessete) ou mais votos, ou reiterada em mais 02 (duas) sessões (art. 103) ${ }^{22}$; no caso do Espírito Santo, se for proferida por mais de 10 (dez) votos ou persistindo a

\footnotetext{
18 Art. 217. Reconhecida a inconstitucionalidade [pelo Tribunal Pleno], as Câmaras poderão declará-la em outros casos, independentemente de pronunciamento do Tribunal Pleno.

19 Art. 240. Declarada a inconstitucionalidade [pelo Conselho Especial], as Câmaras ou as Turmas poderão reconhecê-la em outros casos, independentemente de manifestação do Conselho Especial.

${ }^{20}$ Art. 229. § $2^{\circ}$. A unidade julgadora não submeterá a argüição ao Órgão Especial quando já houver pronunciamento deste ou do plenário do Supremo Tribunal Federal sobre a questão.

${ }^{21}$ Art. 181, Parágrafo único. A argüição de inconstitucionalidade poderá não ser submetida ao Tribunal Pleno quando já houver pronunciamento deste órgão ou do plenário do Supremo Tribunal Federal sobre a questão. Art. 184. A decisão que declarar a inconstitucionalidade será tomada pela maioria absoluta dos Membros do Tribunal.

${ }^{22}$ Art. 103. A decisão que declarar a inconstitucionalidade ou rejeitar a argüição, se for proferida por 17 (dezessete) ou mais votos, ou reiterada em mais 02 (duas) sessões, será de aplicação obrigatória para todos os Órgãos do Tribunal.
} 
rejeição em mais de duas sessões (Art. 167, § $\left.3^{0}\right)^{23}$; nos casos de Roraima (art. 218, parágrafo único ${ }^{24}$, Rio Grande do Sul (art. 211) ${ }^{25}$ e Maranhão (art. 484) ${ }^{26}$, se proferida por maioria de dois terços do Pleno; e no caso de Pernambuco, "se for reiterada em mais de duas sessões" (art. 139) ${ }^{27}$. Embora não faça referência, neste dispositivo, a um quorum específico para tornar obrigatória a decisão do pleno, o regimento interno do tribunal de Pernambuco estabelece no dispositivo anterior (art. 138), como regra geral, que, para a declaração de inconstitucionalidade de uma lei, são necessários os votos de 2/3 dos Desembargadores da Corte Especial ${ }^{28}$, o que é curioso, pois contraria o disposto no art. 97 da Constituição da República, que demanda o voto apenas da maioria absoluta dos seus membros, e não de uma maioria qualificada.

Embora a decisão do pleno, nestas hipóteses, vincule os órgãos fracionários, os regimentos destes tribunais (à exceção de Roraima, que é silente a este respeito) admitem de forma expressa que os órgãos fracionários suscitem novamente a manifestação do pleno, devendo para tanto apontar um motivo relevante que poderia levá-lo a rever seu entendimento ${ }^{29}$.

Vale ainda registrar que os regimentos dos tribunais do Maranhão, Rio de Janeiro, Espírito Santo e Pernambuco fazem referência a eventual decisão do STF sobre a questão - e o fazem, praticamente todos, com a mesma redação:

\footnotetext{
${ }^{23}$ Art. 167, § $3^{\circ}$. A decisão que declarar a inconstitucionalidade, rejeitar a argüição por mais de 10 (dez) votos ou persistindo a rejeição em mais de duas sessões, será de aplicação obrigatória para todos dos órgãos públicos [sic].

${ }^{24}$ Art. 218, Parágrafo único. A decisão declaratória ou denegatória da inconstitucionalidade, se proferida por maioria de dois terços do Pleno, constituirá, para o futuro, decisão de aplicação obrigatória em casos análogos.

${ }^{25}$ Art. 211. A decisão declaratória ou denegatória da inconstitucionalidade, se proferida por maioria de dois terços, constituirá, para o futuro, decisão de aplicação obrigatória em casos análogos, salvo se algum órgão fracionário, por motivo relevante, entender necessário provocar novo pronunciamento do Órgão Especial sobre a matéria.

${ }^{26}$ Art. 484. A decisão declaratória ou denegatória de inconstitucionalidade, se proferida por maioria de dois terços, constituirá, para o futuro, decisão de aplicação obrigatória em casos análogos, salvo se alguma câmara, por motivo relevante, entender necessário provocar novo pronunciamento do Plenário sobre a matéria.

${ }^{27}$ Art. 139. A decisão que declarar a inconstitucionalidade ou rejeitar a argüição, se for reiterada em mais de duas sessões, será de aplicação obrigatória para todos os órgãos do Tribunal.

${ }^{28}$ Art. 138. Será declarada a inconstitucionalidade se nesse sentido votarem pelo menos dois terços (2/3) dos desembargadores; não alcançado o quorum, considerar-se-á rejeitada a argüição (art. $125 \S 2^{\circ}$ ).

${ }_{29}$ A redação do dispositivo dos regimentos dos tribunais do Rio de Janeiro, Espírito Santo e Pernambuco, a este respeito, é exatamente a mesma: "Qualquer Órgão Julgador, por motivo relevante reconhecido pela maioria de seus membros, poderá provocar novo pronunciamento do Órgão Especial [Tribunal Pleno /Corte Especial], salvo se a Assembléia Legislativa já houver suspendido a execução da lei ou ato normativo declarado inconstitucional." [RITJRJ, Art. 103, $\S 2^{\circ}$; RITJES, Art. 167, § 50; RITJPE Art. 139, § $2^{\circ}$ ]. Os dispositivos dos regimentos dos Tribunais do Rio Grande do Sul e Maranhão são os já citados arts. 211 (RITJRS) e 484 (RITJMA).
} 
Cessará a obrigatoriedade a que se refere o caput deste artigo se sobrevier decisão, em sentido contrário, do Supremo Tribunal Federal, tratando-se da Constituição da República, ou do Órgão Especial [Tribunal Pleno /Corte Especial], quando se tratar da Constituição do Estado. [RITJRJ, Art. 103, § 4; RITJES, Art. 167, § 7; RITJPE Art. 139, § 4]

A exceção recai sobre o regimento do tribunal do Maranhão, que basicamente reproduz o que dispõe o parágrafo único do art. 481 do CPC, estabelecendo que:

As câmaras isoladas ou reunidas não submeterão ao Plenário a arguição de inconstitucionalidade se já houver pronunciamento deste ou do Supremo Tribunal Federal sobre a questão. [art. 477, parágrafo único]

Ainda que não se pretenda aqui descer à análise das interpretações possíveis dos dispositivos regimentais, o que demandaria um estudo jurisprudencial junto a cada um dos tribunais citados, assumo que a interpretação mais condizente com o sistema brasileiro de controle de constitucionalidade seria a de que o advento de uma decisão do STF em sede de controle concreto-difuso, seja pela constitucionalidade, seja pela inconstitucionalidade, mas desde que contrária à decisão do Pleno do Tribunal de Justiça, faria apenas cessar a obrigatoriedade ${ }^{30}$ de observância desta pelos órgãos fracionários, sem com isso tornar a decisão do STF de observância compulsória. Nesse sentido, se a decisão do tribunal pleno era, por exemplo, pela inconstitucionalidade de uma lei, e esta decisão deveria ser seguida pelos órgãos fracionários do tribunal, sobrevindo uma decisão do STF, em controle concreto-difuso, pela constitucionalidade da lei, o órgão fracionário estaria livre tanto para (i) aplicar a lei como para (ii) deixar de aplicá-la. No primeiro caso, o faria levando em conta o princípio da presunção de constitucionalidade da lei, a decisão do STF e a norma regimental. No segundo caso, o órgão fracionário o faria levando em conta o parágrafo único do art. 481 do CPC e a decisão do pleno ou órgão especial (que não teria sido superada pela decisão do STF; apenas deixaria de ser de observância obrigatória). É importante lembrar que as declarações de constitucionalidade proferidas pelo STF só terão efeito vinculante quando forem proferidas em ADC, cujo ajuizamento demanda a comprovação da existência de controvérsia judicial relevante sobre a lei em questão (art. 14, III, da Lei 9.868/99). Nem mesmo a improcedência de uma ADI poderia ter o efeito de tornar obrigatório o entendimento pela constitucionalidade de uma lei, já que o ajuizamento de ADI não pressupõe a existência de "controvérsia judicial relevante", que é exigida para o ajuizamento da ADC, comprometendo assim a idéia tão difundida de ambivalência das ações constitucionais.

\footnotetext{
${ }^{30}$ Afinal, esta é a expressão utilizada pelos regimentos dos tribunais citados (à exceção do RI do TJ do Maranhão).
} 
A referência feita à decisão do próprio Tribunal Pleno (ou órgão especial) também é curiosa. Afinal, o que o dispositivo determina, colocado em outros termos, é que a decisão do Tribunal Pleno deixará de ser de observância obrigatória se o próprio Tribunal Pleno decidir posteriormente de outra forma... Se esta idéia já parece estranha, pela obviedade que lhe é inerente, a estranheza ainda se agrava pelo fato de que o dispositivo limita o caso à decisão que tem por base a Constituição Estadual, o que sugeriria que a decisão que tivesse por base a Constituição da República não teria o mesmo efeito. É provável que o dispositivo refira-se às decisões proferidas em sede de controle abstrato-concentrado, o que justificaria esta distinção entre TJ-Constituição do Estado e STF-Constituição da República, mas não a redação escolhida para a norma regimental, que permaneceria confusa ou redundante e desnecessária.

De todo modo, nota-se, a partir dos dispositivos regimentais citados que decisão vinculante não significa decisão definitiva, podendo ser revista, mesmo que se trate de declaração de inconstitucionalidade.

Os regimentos dos Tribunais de Santa Catarina ${ }^{31}$, Bahia ${ }^{32}$, Amazonas $^{33}$, Rondônia ${ }^{34}$, Paraíba $^{35}$, Mato Grosso do Sul $^{36}$ e Rio Grande do Norte ${ }^{37}$ têm em comum a exigência de uma manifestação unânime por parte dos membros do Tribunal Pleno para que a decisão deste seja de observância obrigatória aos órgãos fracionários. Por outro lado, alguns destes regimentos deixam claro que os órgãos fracionários estão dispensados de encaminhar ao pleno uma questão constitucional já resolvida por este, ainda que não tenha alcançado a unanimidade ${ }^{38}$.

\footnotetext{
${ }^{31}$ Art 160. A decisão declaratória, ou denegatória da inconstitucionalidade, se unânime, torna-se, para o futuro, de aplicação obrigatória aos casos análogos, pelas Câmaras, salvo se qualquer destas, por motivo relevante, achar necessário provocar novo pronunciamento do Tribunal Pleno sobre a matéria.

32 Art. 229. A decisão declaratória ou negatória de inconstitucionalidade, se for unânime, passará a ser decisão definitiva, de aplicação obrigatória nos casos análogos, salvo se o Órgão Julgador, por motivo relevante, achar necessário provocar novo pronunciamento do Tribunal Pleno. ${ }_{33}$ Art. $154, \S 7^{\circ}$. A decisão declaratória ou negatória da inconstitucionalidade, se for unânime, constituirá, para o futuro, decisão definitiva e de aplicação obrigatória nos casos análogos, salvo se a Câmara ou o Tribunal, por motivo relevante, achar necessário provocar novo pronunciamento sobre a matéria, ou provada decisão em contrário do S.T.F.

${ }^{34}$ Art. 546, § $2^{\circ}$. A decisão declaratória ou denegatória da inconstitucionalidade, se for unânime, constituirá, para o futuro, decisão vinculativa para os casos análogos, salvo se o órgão judicante, por motivo de força relevante, considerar necessário provocar nova manifestação do Tribunal Pleno.

${ }_{35}$ Art. $211, \S 6^{\circ}$. O julgamento, seja declaratório ou denegatório da inconstitucionalidade, e sendo unânime, constituirá precedente na uniformização da jurisprudência.

${ }_{36}$ Art. 587, § $2^{\circ}$. A decisão declaratória ou denegatória da inconstitucionalidade, se for unânime, constituirá, para o futuro, decisão vinculativa para os casos análogos, salvo se o órgão judicante, por motivo relevante, considerar necessário provocar nova manifestação do Tribunal Pleno sobre a matéria.

${ }^{37}$ Art. 243. A decisão declaratória ou denegatória da inconstitucionalidade, quando unânime, terá aplicação obrigatória para o futuro aos casos análogos, ressalvadas as seguintes hipóteses: (...) ${ }^{38}$ RITJSC, Art. 160. Parágrafo único. Poderá a Câmara dispensar a remessa dos autos ao Tribunal
} 
Esta forma de disciplinar a matéria deixa ainda mais clara a distinção entre vinculação ao que for decidido pelo tribunal pleno (o que, no caso destes tribunais, só ocorre quando a decisão deste for unânime) e simples dispensa de encaminhamento da questão quando já houver decisão do pleno a respeito, sem ter alcançado a unanimidade exigida para a vinculação. Esta diferenciação entre vinculação e dispensa de encaminhamento revela uma compreensão mais aberta, pluralista e, consequentemente, democrática de interpretação constitucional e controle de constitucionalidade das leis, pois abre espaço para as saudáveis divergências entre os órgãos jurisdicionais neste processo hermenêutico, valendo frisar que mesmo as decisões do tribunal pleno tomadas à unanimidade, e que, portanto, vinculam os órgãos fracionários, podem ser revistas se estes, por motivo relevante, julgarem necessário provocar novo pronunciamento do Tribunal Pleno sobre a questão.

A forma como estes tribunais disciplinaram a cláusula de reserva de plenário parece confirmar a idéia aqui sustentada de que o parágrafo único do art. 481 do CPC não deve ser interpretado como uma restrição aos órgãos fracionários no processo de interpretação constitucional e controle de constitucionalidade das leis, aproximando-se o dispositivo processual mais de uma dispensa de encaminhamento do que de uma vinculação. Por outra: o dispositivo processual não deve ser compreendido como uma restrição imposta aos órgãos fracionários do Tribunal, mas como uma liberação, apoiada na jurisprudência do pleno ou do STF.

O regimento do Tribunal de Justiça da Bahia reforça ainda mais esta idéia, pois reproduz, em seu art. 227 , parágrafo único ${ }^{39}$, a redação do parágrafo único do art. 481 do CPC, para, a seguir, disciplinar as hipóteses de vinculação e de mera dispensa de encaminhamento da questão.

Já o regimento do Tribunal de Justiça do Rio Grande do Norte parece tomar outro rumo, ao menos em relação às decisões do STF. De fato, após dispor que "a decisão declaratória ou denegatória da inconstitucionalidade, quando unânime, terá aplicação obrigatória para o futuro aos casos análogos",

Pleno, quando este, embora sem unanimidade, houver firmado jurisprudência uniforme sobre a questão constitucional.

RITJBA, Art. 230. Poderá também o Órgão Julgador dispensar a remessa dos autos ao Tribunal Pleno, quando este, embora com votos divergentes, houver firmado jurisprudência uniforme sobre a matéria da prejudicial.

RITJRO, Art. 546, § $3^{\circ}$. Poderá a Câmara dispensar a remessa dos autos ao Pleno, quando este houver firmado jurisprudência uniforme sobre a matéria da prejudicial.

RITJMS, Art. 587, $₹ 3^{\circ}$. Poderá também o órgão julgador, dispensar a remessa dos autos ao Tribunal Pleno, quando este, embora com votos divergentes, houver firmado jurisprudência uniforme sobre a matéria da prejudicial.

RITJRN, Art. 243, § $2^{\circ}$. Poderá a Câmara deixar de remeter os autos ao Tribunal Pleno, quando este, embora por maioria de votos, houver firmado jurisprudência uniforme sobre a mesma matéria constitucional.

${ }^{39}$ Art. 227, Parágrafo único. As Turmas, Câmaras e Seções não submeterão ao Tribunal Pleno a argüição de inconstitucionalidade, quando já houver pronunciamento deste ou do plenário do Supremo Tribunal Federal sobre a questão. 
o art. 243 do regimento daquele tribunal faz uma ressalva em relação a três hipóteses, a saber:

I - se houver alteração do texto constitucional em que se fundamentou a decisão;

II - se o Plenário do Supremo Tribunal Federal decidir contrariamente sobre a mesma lei ou ato idêntico inquinado de inconstitucional, mesmo que não conste ainda de súmula;

III - se houver possibilidade de modificação do pronunciamento do Tribunal Pleno, pela mudança de sua composição ou apresentação de novos fundamentos jurídicos, a critério da Câmara julgadora.

Em seguida, dispõe no parágrafo primeiro do referido artigo que, "ocorrendo a circunstância prevista no inciso II, aplica-se a jurisprudência do Excelso Pretório", o que sugere não uma liberação, mas uma vinculação dos órgãos fracionários ao que for decidido pelo STF resultando na peculiar situação onde apenas o STF e os juízes de primeira instância terão plena liberdade para interpretar a Constituição.

Os regimentos dos tribunais de Mato Grosso ${ }^{40}$, Amapá ${ }^{41}$, São Paulo ${ }^{42}$, Tocantins $^{43}$, Minas Gerais ${ }^{44}$, Paraná $^{45}$ e Pará $^{46}$ estabelecem que, na apreciação

${ }^{40}$ Art. 169. A decisão que declarar ou rejeitar a inconstitucionalidade constituirá, para o futuro, decisão vinculativa a todos os órgãos do Tribunal nos casos análogos, salvo se qualquer deles, por motivo relevante, entender necessário provocar novo pronunciamento do Tribunal Pleno sobre a matéria, ou se houver ulterior decisão, em sentido contrário, do Supremo Tribunal Federal, tratando-se da Constituição da República ou do próprio Tribunal, quando se tratar da Constituição do Estado.

${ }^{41}$ Art. 188. A Secção ou a Câmara Únicas, no caso de argüição de inconstitucionalidade, envolvendo questão ainda não decidida pelo Pleno, remeterá o feito a esse órgão.

${ }^{42}$ Art. $191, \S 2^{\circ}$. Somente se houver motivo relevante, poderá ser renovado o incidente.

43 Art. 142. A decisão que declarar a inconstitucionalidade ou rejeitar a argüição será de aplicação obrigatória para todos os órgãos do Tribunal.

$\S 2^{\circ}$. Qualquer órgão julgador, por motivo relevante, reconhecido pela maioria de seus membros, poderá provocar novo pronunciamento do Tribunal, Câmara ou Turma, salvo se a Assembléia Legislativa já houver suspendido a execução da lei ou ato normativo declarado inconstitucional.

${ }^{44}$ Art. 248. Submetida a questão da inconstitucionalidade de lei ou de ato normativo do poder público ao órgão a que tocar o conhecimento do processo, será a argüição levada ao julgamento da Corte Superior, se reconhecida a sua relevância.

$\S 1^{\circ} \mathrm{A}$ argüição será tida como irrelevante quando:

I - já houver sido decidida pelo Supremo Tribunal Federal;

II - já houver sido decidida pela Corte Superior;

III - for inequivocamente improcedente;

IV - o julgamento, pelo órgão a que couber o conhecimento do processo em que se levantou a argüição, puder ser feito independentemente da questão constitucional.

$\S 2^{\circ}$ Nas hipóteses dos incisos II, III e IV do parágrafo anterior, qualquer dos julgadores do órgão perante o qual haja sido levantada a argüição, a parte que o tenha feito ou o Ministério Público, se lhe couber intervir no processo, poderá pedir que a questão de relevância seja reexaminada pela Corte Superior.

${ }^{45}$ Art. 270. As Seções e as Câmaras, sempre que se inclinarem pela inconstitucionalidade de lei ou de ato normativo, determinarão a remessa do processo ao Órgão Especial. 
do incidente de inconstitucionalidade, qualquer decisão do pleno, seja pela constitucionalidade ou pela inconstitucionalidade da lei, vincula os demais órgãos do tribunal na aplicação do ato normativo em casos futuros. É dizer, basta uma decisão do pleno, pelo quorum constitucional de maioria absoluta (art. 97, CRFB), para que seja firmado o entendimento a ser aplicado por todos os órgãos fracionários do tribunal no julgamento de casos análogos. Este procedimento é plenamente justificável no caso do tribunal do Amapá, que tem no total apenas 9 desembargadores e onde, portanto, o pleno praticamente se confunde com os órgãos que o integram (aliás, Câmara e Seção Únicas). Mas causa certo espanto no caso do tribunal de São Paulo, onde um único entendimento de 13 desembargadores (maioria absoluta dos 25 membros do órgão especial) vincula imediatamente todos os 352 magistrados que integram o tribunal.

À exceção do regimento do tribunal do Amapá, que não tem disposição expressa nesse sentido, todos os demais admitem que a questão seja novamente encaminhada ao pleno (ou órgão especial), caso haja motivo relevante para tanto. O regimento do tribunal do Mato Grosso, tal como os regimentos já citados dos tribunais do Rio de Janeiro, Espírito Santo e Pernambuco, dispõe que a decisão do pleno deixará de ser obrigatória aos órgãos fracionários "se houver ulterior decisão, em sentido contrário, do Supremo Tribunal Federal, tratando-se da Constituição da República ou do próprio Tribunal, quando se tratar da Constituição do Estado" (art. 169).

O regimento do tribunal de Minas Gerais adotou uma posição peculiar em relação aos demais, ao dispor que:

Art. 248. Submetida a questão da inconstitucionalidade de lei ou de ato normativo do poder público ao órgão a que tocar o conhecimento do processo, será a argüição levada ao julgamento da Corte Superior, se reconhecida a sua relevância.

$\S 1^{\circ} \mathrm{A}$ argüição será tida como irrelevante quando:

I - já houver sido decidida pelo Supremo Tribunal Federal;

II - já houver sido decidida pela Corte Superior;

III - for inequivocamente improcedente;

Parágrafo único. Igual procedimento será adotado quando as Seções ou Câmaras, embora não declarando expressamente a inconstitucionalidade de lei ou ato normativo do poder público, afastam sua incidência, no todo ou em parte.

Art. 272. A decisão declaratória ou denegatória da inconstitucionalidade, se proferida por maioria absoluta, constituirá, para o futuro, decisão de aplicação obrigatória em casos análogos, salvo se algum órgão fracionário, por motivo relevante, entender necessário provocar novo pronunciamento do Órgão Especial sobre a matéria.

${ }_{46}$ Art. 149. A decisão declaratória ou denegatória da inconstitucionalidade, se proferida por maioria de dois terços (2/3), constituirá para o futuro, decisão de aplicação obrigatória, em casos análogos, salvo se algum Órgão fracionário, por motivo relevante, entender necessário provocar novo pronunciamento do Tribunal Pleno sobre a matéria. 
IV - o julgamento, pelo órgão a que couber o conhecimento do processo em que se levantou a argüição, puder ser feito independentemente da questão constitucional.

$\S 2^{\circ}$ Nas hipóteses dos incisos II, III e IV do parágrafo anterior, qualquer dos julgadores do órgão perante o qual haja sido levantada a argüição, a parte que o tenha feito ou o Ministério Público, se the couber intervir no processo, poderá pedir que a questão de relevância seja reexaminada pela Corte Superior. (grifei)

Como se pode notar, não há possibilidade de encaminhamento da questão ao pleno, sequer para reexame, se já houver decisão do STF sobre a matéria, o que é uma leitura bastante singular do parágrafo único do art. 481 do CPC, se comparada com a forma como os demais regimentos disciplinam a cláusula de reserva de plenário.

\section{ANÁLISES E CONCLUSÕES}

A pesquisa realizada junto aos tribunais de justiça do país, voltada à identificação do tratamento conferido em seus regimentos internos à cláusula de reserva de plenário, embora humilde em seus propósitos, revelou pontos importantes para uma melhor compreensão do sistema brasileiro de controle de constitucionalidade. A diversidade normativa no que tange à matéria, afirmada na introdução e confirmada ao longo do trabalho, impõe certo cuidado na interpretação do art. 481, parágrafo único norma do CPC, uma vez que revela diferentes compreensões sobre o sentido, o conteúdo e/ou o alcance da norma processual. Além disso, a pesquisa revelou um grau de divergência considerável, sobretudo no ponto que assumo como o mais relevante, a saber: os efeitos da decisão do STF no controle de constitucionalidade exercido pelos tribunais.

A idéia de que o Brasil caminha para uma concentração no controle de constitucionalidade, ou mais precisamente a forma como esta idéia tem se propagado, desacompanhada de um debate sério, profundo e honesto, revela-se no mínimo preocupante, em razão de pelo menos uma importante conseqüência que tem sido ocultada ou que ao menos não tem sido discutida de forma clara: a centralização da interpretação do texto constitucional - ou, colocado em termos talvez mais dramáticos, mas não menos verdadeiros, a exclusão de diversos setores da sociedade (incluindo os demais órgãos do Poder Judiciário) do processo de interpretação da Constituição. A ausência de um debate sobre este ponto - sonegado em meio à campanha pela centralização do controle de constitucionalidade - dificulta se não mesmo impede que se identifique uma legitimidade na proposta, que, aliás, parece conquistar espaço apenas quando resulta de procedimentos exclusivos do STF, ou seja, em sua própria jurisprudência e no seu regimento interno. Este ponto merece ser desenvolvido em estudo posterior - e assim será. Por ora, interessa apenas ressaltar que, considerando-se este contexto, é no mínimo curioso, se não também revelador ou ao menos sugestivo o fato de 
que neste universo de 27 regimentos internos somente 10 fazem alguma menção ao STF quando disciplinam a cláusula de reserva de plenário (sendo que 4 apenas reproduzem o dispositivo do CPC). É dizer: 17 tribunais de justiça não levaram em consideração a jurisprudência do STF no exercício do controle concreto-difuso de constitucionalidade.

O método empregado neste trabalho - limitado à análise dos textos normativos sem considerar a forma como são interpretados na prática - não permite que sejam extraídas conclusões seguras a partir destes dados. Ademais, é tarefa sempre difícil interpretar o silêncio. E, de todo modo, a norma do CPC independe de reprodução em sede regimental para ser cumprida (o que poderia até ser uma das razões para esta omissão: a redundância). Ainda assim é curioso. E, no contexto apontado acima, pode ser sugestivo. Pode indicar uma saudável e democrática divergência em relação à idéia de concentração do controle de constitucionalidade e, como conseqüência, da interpretação da Constituição exclusivamente no âmbito do STF. Considero a hipótese plausível, pois a idéia de concentração do controle de constitucionalidade, embora gere uma redistribuição de poder, tem sido propagada basicamente por aqueles que mais se beneficiariam dela: os ministros do próprio STF, e que o fazem a partir de leituras principiológicas questionáveis ou idiossincráticas (STF como guardião da Constituição) ${ }^{47}$ e de referências a modelos estrangeiros escolhidos arbitrariamente (em especial, o Tribunal Constitucional alemão) ${ }^{48}$. Não participam desta campanha justamente aqueles que, em termos objetivos, perdem poder nesta redistribuição de competências promovida pelo STF. Assim, e considerando-se que o STF tem promovido esta mudança em sede jurisprudencial ou com base em seu próprio regimento interno, o que significa dizer que a Corte não o faz a partir de normas constitucionais claras ou mesmo leis federais que explicitem uma vontade popular nesse sentido, pode-se arriscar que o silêncio dos tribunais de justiça, neste caso, deixa de ser meramente curioso e passa a ser também sugestivo.

O trabalho também demonstrou que dos 27 regimentos internos, 7 não estabelecem uma vinculação entre a decisão do pleno e os casos futuros a serem julgados pelos órgãos fracionários, ao passo que 20 admitem esta possibilidade. Destes 20 regimentos, 7 exigem decisão unânime para que haja vinculação, outros 6 definem um quorum qualificado para tanto, e os 7 restantes estabelecem que qualquer decisão do pleno ou do órgão especial vincula os órgãos fracionários. Mas, em qualquer caso, verificou-se que decisão vinculante não significa decisão definitiva, uma vez que os regimentos (em sua maioria) admitem explicitamente que os órgãos fracionários

\footnotetext{
${ }^{47}$ Não qualifico como idiossincrática a idéia de considerar o STF como guardião da Constituição, mas a leitura que tem sido feita disso.

${ }^{48}$ Por que devemos interpretar o STF a partir do modelo alemão - que sequer foi o mais citado no processo constituinte?
} 
suscitem novamente a manifestação do pleno, devendo para tanto apontar um motivo relevante que poderia levá-lo a rever seu entendimento.

Outra distinção identificada neste trabalho foi entre vinculação dos órgãos fracionários à decisão do tribunal pleno e simples dispensa de encaminhamento da questão quando já houver decisão do pleno a respeito. Esta diferenciação, é importante reafirmar, revela uma compreensão mais aberta, pluralista e, consequentemente, democrática de interpretação constitucional e controle de constitucionalidade das leis, abrindo espaço para as saudáveis divergências entre os órgãos jurisdicionais neste processo hermenêutico.

Se os tribunais (a maioria absoluta, ao menos) interpretaram dessa forma o art. 481 parágrafo único do CPC no que tange às decisões do pleno ou do órgão especial, não parece haver razão para não estender este entendimento às decisões do STF (em controle concreto-difuso), também consideradas na norma processual. Proponho, então, que o parágrafo único do art. 481 do CPC não deve ser compreendido como uma restrição imposta aos órgãos fracionários do Tribunal, mas como uma liberação, apoiada na jurisprudência do pleno ou do STF.

\section{REFERÊNCIAS BIBLIOGRÁFICAS}

AGRA, Walber de Moura. Curso de Direito Constitucional. 4. ed. Rio de Janeiro: Forense, 2008.

BARROSO, Luís Roberto. O Controle de Constitucionalidade no Direito Brasileiro. 3. ed. São Paulo: Saraiva, 2008.

CAMARA, Alexandre Freitas. Lições de Direito Processual Civil. 2. ed., vol. II. Rio de Janeiro: Lúmen Júris, 1999.

DIDIER JR., Fredie, e CUNHA, Leonardo Carneiro da. Curso de Direito Processual Civil - Meios de Impugnação às Decisões Judiciais e Processo nos Tribunais. 9. ed. Vol. 3. Salvador: Editora Podium, 2011, p. 577.

DONIZETTI, Elpídio. Curso Didático de Direito Processual Civil. 6. ed. Belo Horizonte: Del Rey, 2005, p. 347.

LEITE, Fábio Carvalho. ADIN e ADC, e a ambivalência possível: uma proposta. In: Revista de Direito do Estado (RDE), vol. 10, Rio de Janeiro: Ed. Renovar, 2008, pp. 67-99.

NERY JR., Nelson, e NERY, Rosa Maria de Andrade. Código de Processo Civil Comentado e Legislação Processual Civil Extravagante em Vigor. 6. ed. São Paulo: Editora Revista dos Tribunais, 2002, p. 790.

THEODORO JR., Humberto. Curso de Direito Processual Civil. 40. ed. Vol. 1. Rio de Janeiro: Editora Forense, 2002, p. 599. 